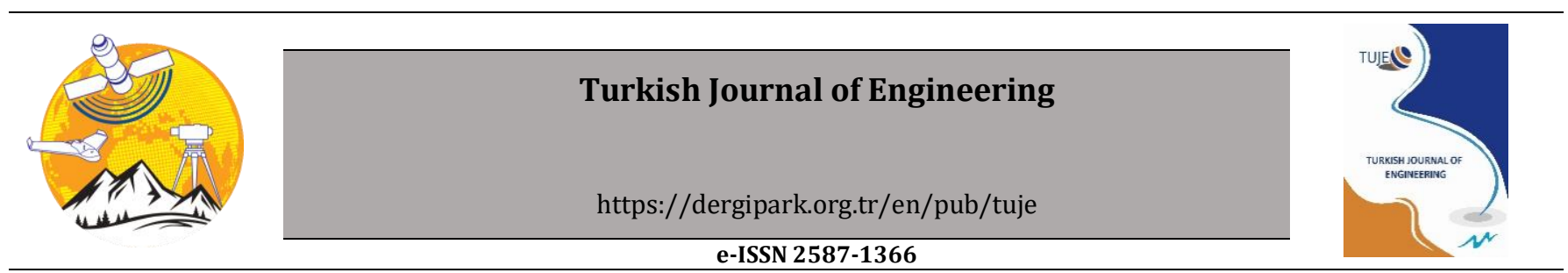

\title{
Investigation of efficiency of R717 refrigerant single stage cooling system and R717/R744 refrigerant cascade cooling system
}

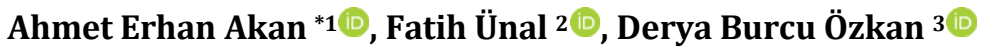 \\ ${ }^{1}$ Namık Kemal University, Çorlu Vocational School, Machinery and Metal Technologies, Tekirdağ, Turkey \\ 2Mardin Artuklu University, Mardin Vocational School, Machinery and Metal Technologies, Mardin, Turkey \\ ${ }_{3}^{3}$ Yildiz Technical University, Engineering Faculty, Mechanical Engineering, İstanbul, Turkey
}

\author{
Keywords \\ Cooling \\ Cascade systems \\ Refrigerant \\ Efficiency \\ Thermodynamic analysis
}

\begin{abstract}
This study is an adaptation of ammonia cascade cooling systems using carbon dioxide on ice cream production machines and includes thermodynamic analysis of R717/R744 cascade refrigeration system with $\mathrm{R} 717$ refrigerant single-stage refrigeration system and investigation of its efficiency. As a result of the analyses, the COP value of the single-stage system was 3.67, the Carnot efficiency was 0.57 , the second law efficiency was 0.19 and the power required to operate the compressor was $27.55 \mathrm{~kW}$. In the cascade cooling system, the COP value was 4.46, the Carnot efficiency 0.59 and the compressor power $22.7 \mathrm{~kW}$ in the high-temperature part, while the COP value was measured as 14.65 , the Carnot efficiency 0.58 and the compressor power $6.4 \mathrm{~kW}$ in the low-temperature part. For the whole cascade system, the COP 3.24 and the second law efficiency were found to be 0.43 . When the results were compared, it was concluded that although the COP value of the cascade cooling system was 0.43 points lower than the single-stage ammonia system, when our country's climate conditions and the thermophysical properties carbon dioxide gas were considered together, one of the most suitable designs was the cascade cooling system.
\end{abstract}

\section{INTRODUCTION}

Ice cream is known as a popular nutrient for people because of its superior nutritional value, easy digestion, popular taste, aroma and refreshing effect. Today, the ice cream industry is developing rapidly. In this study, ice cream production processes to be examined are shown in Figure 1.

The mixture, which has matured, must be frozen in special machines in order to become freeze. The function of freezing is to freeze some of the water in the mixture. The freezing temperature varies depending on the type of freezer and the composition of the mixture but is generally between $-3.5^{\circ} \mathrm{C}$ and $-5.5^{\circ} \mathrm{C}$. The freezing process is the most important stage of industrial ice cream production. However, this process needs to be studied in terms of energy consumption and efficiency. As an alternative to the single-stage mechanical compression cooling system used in the freezing process, cascade cooling systems can be preferred. The cascade cooling systems are suitable for use in industrial applications, especially in the supermarket refrigeration industry, where the evaporation temperature of frozen food cabinets varies from $-30^{\circ} \mathrm{C}$ to $-50^{\circ} \mathrm{C}$ (Getu and Bansal 2007). Prepare your manuscript and illustrations in appropriate format, according to the instructions given below. Please also be sure that your paper conforms to the scientific and style instructions of the Journal, given below here.

When the studies in the literature on cascade cooling systems examined;

Dopazo et al. (2009) analyzed a $\mathrm{CO}_{2} / \mathrm{NH}_{3}$ cascade cooling system and determined the optimum $\mathrm{CO}_{2}$ condensation temperature from the energy and exergy perspectives. The effects of operating parameters on the performance of a $\mathrm{CO}_{2} / \mathrm{NH}_{3}$ cascade cooling system were experimentally investigated by (Bingming et al. 2009). The researchers observed that the COP value of the system was only slightly sensitive to the degree of overheating, but also was greatly affected by the temperature, evaporation, and condensation of the temperature differences in the graded heat exchanger. 
Dopazo and Fernández-Seara (2011), experimentally evaluated the $\mathrm{CO}_{2} / \mathrm{NH}_{3}$ cascade cooling system in an industrial freezer with an evaporation temperature of $50^{\circ} \mathrm{C}$. They also investigated the effect of operating parameters on system performance and compared the results of common $\mathrm{NH}_{3}$ two-stage cooling systems under the same operating conditions. They found that the COP of the cascade system had about $20 \%$ higher COP than a two-stage ammonia system with economizer and intercooler. Rezayan and Behbahaninia (2011), developed a thermo economic optimization for a simple $\mathrm{CO}_{2} / \mathrm{NH}_{3}$ cascade cooling system without considering environmental analysis. They also investigated the effect of design parameters on the total annual cost of the system where ambient temperature, cooling capacity, and cold space temperature were limited. Özyurt et al. (2016), conducted a thermodynamic analysis of the cooling system operating under two-stage and subcritical conditions using R717 (ammonia) in the hightemperature cycle and R744 (carbon dioxide) in the lowtemperature cycle in their study. They carried out energy and exergy analyses in order to improve the optimum working conditions, performance coefficient and the efficiency of the second law in the cascade condenser of the cooling system and each equipment. By calculating the mass, energy, and exergy equations of the cascade cooling system, they calculated the optimum cascade condenser temperature. Moreover, researchers showed that increasing the evaporation temperature, superheating value, and super cooling value had a positive effect on the performance coefficient value. In a master's study, which was conducted by Alan (2011), the energy-saving potential of the two-stage overcritical $\mathrm{CO}_{2}$ cycle was theoretically examined. Evaporator and gas cooler pressures were taken with variable parameters and how the performance coefficient is affected in the case of expansion turbines instead of the expansion valve was observed.

As can be seen from the aforementioned researches, studies are being carried out to find environmentally compatible refrigerant solutions instead of chlorofluorocarbons (CFC) and hydro chlorofluorocarbons (HCFC) which are used in cooling systems that accelerate global warming, have harmful effect to the ozone layer, and have a negative impact on the environment. Hydro fluorocarbons (HFCs) are obtained by synthesis from natural gases such as chlorine-free ethane and methane, which substitute hydrogen for chlorine and are therefore defined as relatively more environmentally friendly. Natural refrigerants that do not affect global warming and do not harm the ozone layer are undoubtedly the most important alternatives in this process. $\mathrm{CO}_{2}$ gas is one of the natural gases used for cooling. Supermarkets and cold stores require cooling at very low temperatures. Cooling at very low temperatures is either impossible or very difficult with single-stage cooling systems. However, in the low-temperature range of cascade systems, halogenated hydrocarbons are not the first choice that comes to mind because of their relatively insufficient thermo physical properties. Thus, there is a tendency to use carbon dioxide at the low-temperature stage. The superior heat transfer capability and large volumetric capacity of carbon dioxide make it possible to use in the cascade cooling systems with the lowtemperature range. Furthermore, the environmental harm of carbon dioxide and its impact on global warming are less than that of artificial refrigerants. This is another factor that makes carbon dioxide the preferred one instead of others (Çerkezoğlu 2010).

In this study, R717/R744 refrigerant cascade refrigeration system with $\mathrm{R} 717$ refrigerant is used as an alternative to the existing refrigeration system with single-stage mechanical compression, to freeze the ice cream in a factory producing ice cream in addition to the studies in the literature. Thermodynamic analysis of the used cascade cooling and the single-stage cooling systems were made, with the help of the Coolpack program and the systems were compared with each other. The study is thought to be useful in the selection of cooling systems used in the ice cream production.

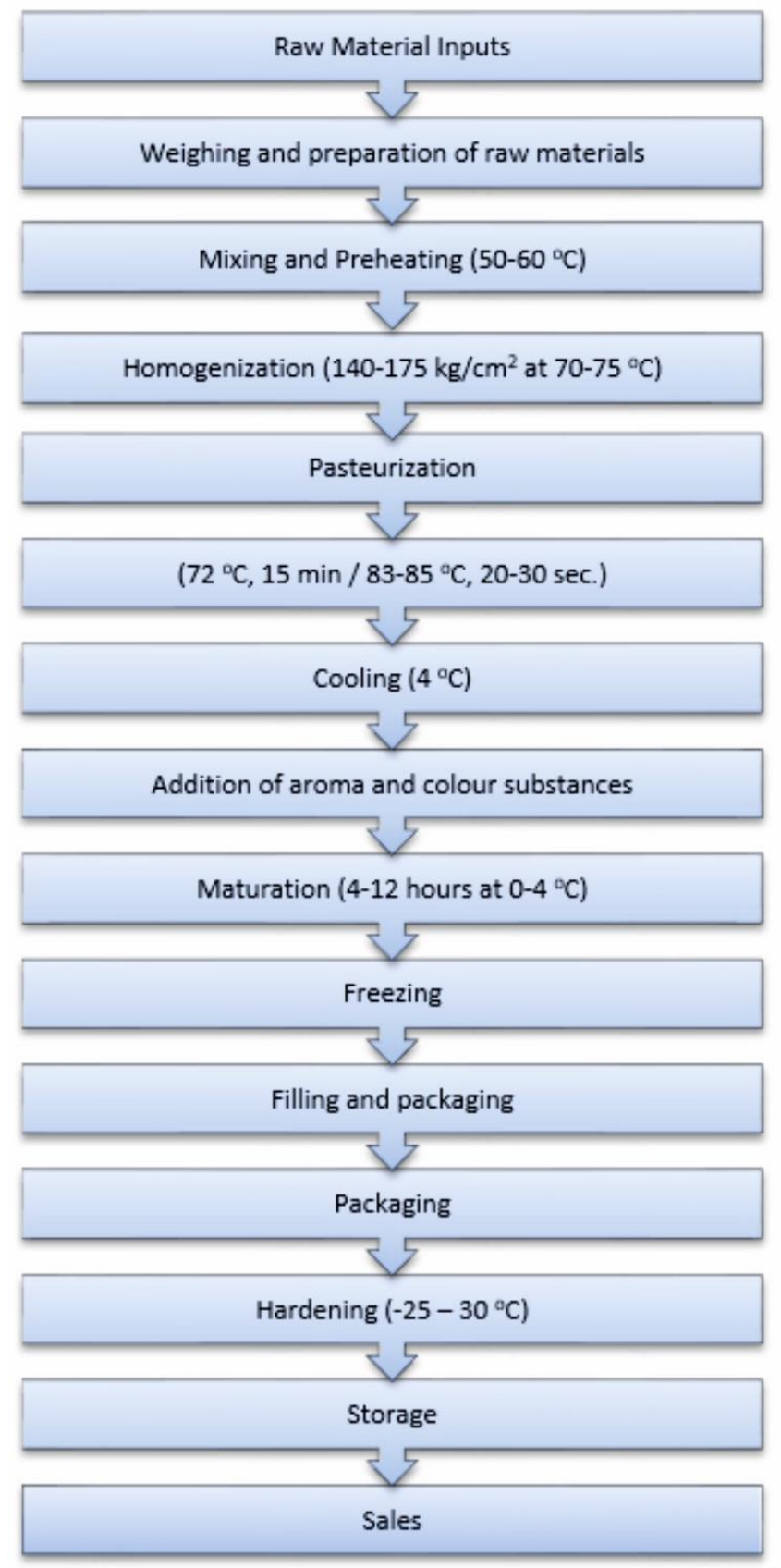

Figure 1. Schematic representation of industrial ice cream production process 


\section{MATERIAL and METHODS}

\subsection{Introduction of Cooling Systems}

The working principle of the vapor cycle cooling system is as follows. The refrigerant vaporized in the evaporator enters the compressor in the vapor phase and is compressed to a certain pressure in the compressor. The temperature of the gas, whose pressure increases, also increases spontaneously. The compressed gas in the compressor then enters the condenser. Condensation occurs at constant pressure in the condenser. The liquid exiting the condenser is subjected to constant enthalpy expansion as it passes through the throttling valve. The refrigerant from the expansion valve is in the form of a liquid-vapor mixture and this mixture enters the evaporator again. The same operations are repeated throughout the cycle (Çerkezoğlu 2010). A schematic representation of the cycle is shown in Figure 2.

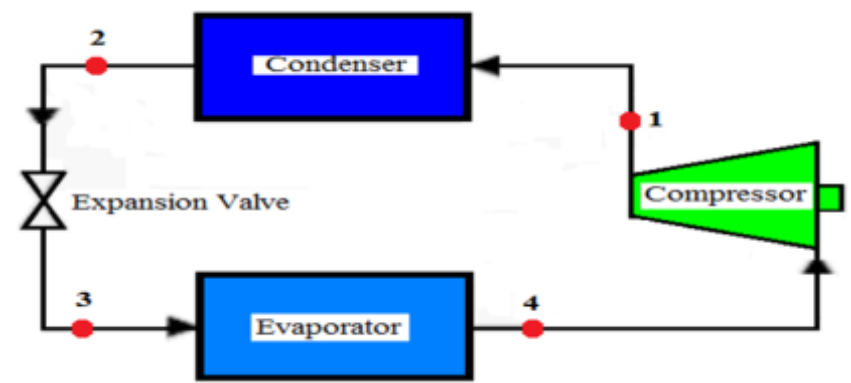

Figure 2. The single-stage mixture refrigeration cycle

In the cycle shown in the Figure 2, the processes occur respectively as follows.

4-1 Adiabatic compression (in compressor)

1-2 Condensation at constant pressure and temperature (in condenser)

2-3 Pressure decrease in constant enthalpy (in expansion valve)

3-4 Evaporation at constant temperature and pressure (in evaporator).

The cascade refrigeration cycle is a cooling cycle consisting of two cycles with two different fluids that do not mix. One of the two cycles is usually the compression cycle, in which heat is transferred to the outside. In these systems, mainly R717 ( $\mathrm{NH}_{3}$, ammonia), R404A and other suitable HFC fluids are being used (Vestergaard 2007). In this type of systems, the working pressure is around 4045 bar (Onbaşıŏglu 2010). The schematic representation of the system is shown in Figure 3 and the In P-h diagram of the cycle is shown in Figure 4.

The state changes occurring in the cascade cycle diagram shown in Figure 3 and Figure 4 are as follows, respectively.

1-2Isentropic compression in the $\mathrm{CO}_{2}$ compressor

2-3Condensation of $\mathrm{CO}_{2}$ at constant pressure in the cascade condenser (barrel type)

3-4Expansion of liquid $\mathrm{CO}_{2}$ in the expansion valve

4-1Evaporation at constant pressure in the evaporator

5-6 Isentropic compression in the R717 compressor

6-7 Condensation at constant pressure in the R717 condenser
7-8 Expansion on constant enthalpy in the R717 expansion valve

8-5Evaporation of $\mathrm{NH}_{3}$ at constant pressure in the cascade condenser (barrel type)

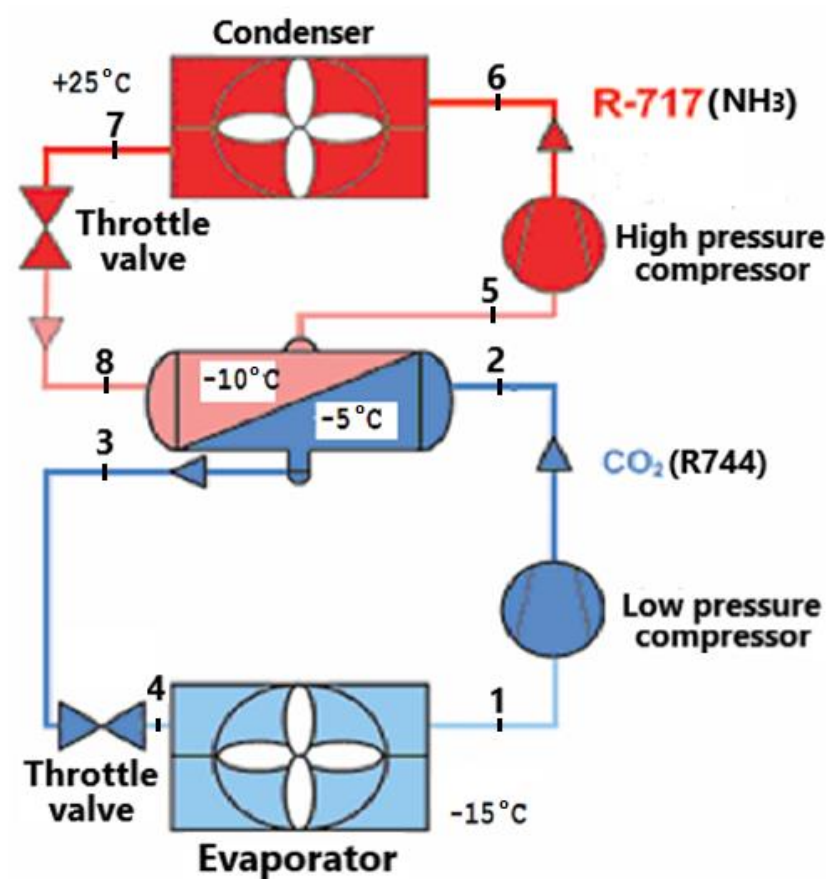

Figure 3. The Cascade cycle diagram (Vestergaard 2007)

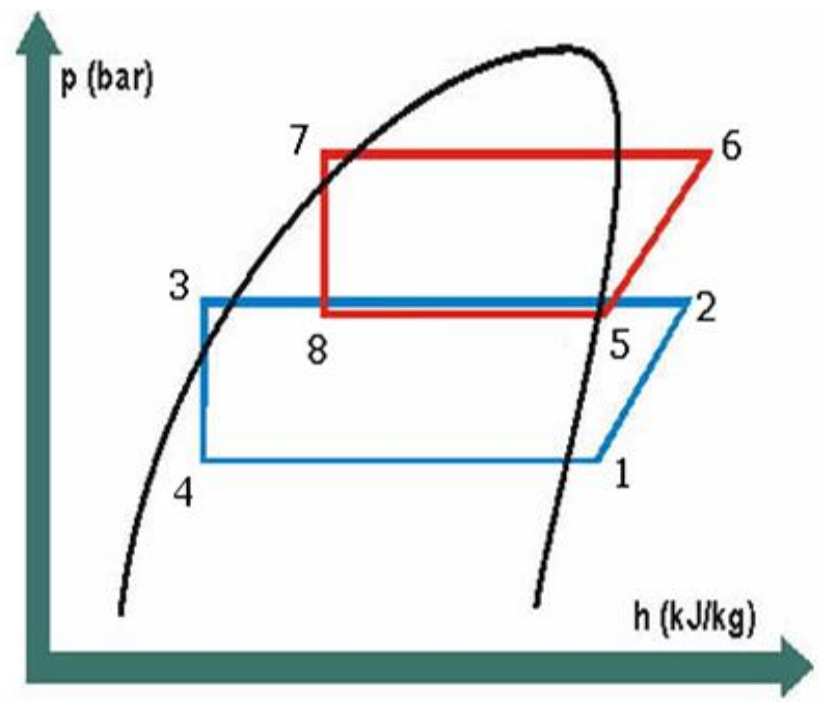

Figure 4. Ln P - h diagram of the Cascade Cycle (Kasap et al. 2011)

\subsection{Determination of Cooling Load}

Assumptions made in calculations;

*The compressors in the systems perform adiabatic compression.

${ }^{*}$ The expansion of the throttling valves takes place at constant enthalpy.

*Kinetic and potential energy changes were neglected.

*Evaporation temperature is $-15^{\circ} \mathrm{C}$, condensation temperature is $25^{\circ} \mathrm{C}$, isentropic efficiency of compressors is $70 \%$ and heat loss rates of compressors are taken as $10 \%$.

*The annual production capacity of the factory is $50 \times 10^{6}$ liters. 
*Density of ice cream is $490 \mathrm{~g} / \mathrm{Lt}$

*Mass flow of ice cream is $0.777 \mathrm{~kg} / \mathrm{s}$.

${ }^{*}$ The specific heat of the milk ( $\mathrm{c}_{\text {milk }}$ ) is $0.94 \mathrm{kcal} / \mathrm{kg}^{\circ} \mathrm{C}$ at $20^{\circ} \mathrm{C}, 0.90 \mathrm{kcal} / \mathrm{kg}^{\circ} \mathrm{C}$ at $4^{\circ} \mathrm{C}$.

*10 people work 20 hours a day around the ice cream machine. The heat emitted by a person; room temperature was accepted as $215 \mathrm{kcal} / \mathrm{h}$ for $20^{\circ} \mathrm{C}$.

${ }^{*}$ In order to illuminate the cooled area, 15 piece 100W fluorescent luminaires have operating 24 hours a day.

*Evaporator has 6 piece fan motors.

*The diameters of the two surfaces of the rotary type hopper are $0.2286 \mathrm{~m}$ and $0.240 \mathrm{~m}$, respectively.

The following formulas were used to determine the heat load.

Depending on the room temperature, the heat load from the cooling of the ice cream was determined with the aid of Equation 1.

$$
\mathrm{Q}=\mathrm{m} \cdot \mathrm{c} \cdot \Delta \mathrm{T}
$$

In Eq. 1, Q is the cooling load (kW), $\mathrm{c}$ is the specific heat of the milk $\left(\mathrm{kcal} / \mathrm{kg}^{\circ} \mathrm{C}\right), \Delta \mathrm{T}$ is the temperature difference $\left({ }^{\circ} \mathrm{C}\right)$.

The heat load from working people and lighting fixtures is obtained with the help of Eq. 2.

$$
\mathrm{Q}=\mathrm{n} \cdot \mathrm{W} \cdot \mathrm{H}
$$

In Eq. 2, $\mathrm{n}$ is the number of elements, $\mathrm{W}$ is element strength (Watt) and $\mathrm{H}$ is the working time of the element.

The heat load caused by electric motors is calculated using Eq. 3.

$$
\mathrm{Q}=\mathrm{n} \cdot \mathrm{W} \cdot \mathrm{qH}
$$

In this Equation, $\mathrm{q}$ is the heat load from the electric motor. If the engine power is between $1 / 8-1 / 2$ HP and the engine and driven elements are in the cold room, this value is taken as 1070 (kcal/hHP).

The heat load resulting from the temperature of the rotary freezer was determined with the help of Eq. 4.

$$
\mathrm{Q}=\mathrm{U} \cdot \mathrm{A} \cdot \Delta \mathrm{T}
$$

In this Equation, $\mathrm{U}$ is the total heat transfer coefficient $\left(\mathrm{W} / \mathrm{m}^{2 \circ} \mathrm{C}\right)$ and $\mathrm{A}$ is the cross-sectional area of the rotor $\left(\mathrm{m}^{2}\right)$.

The formulas used in the selection of system elements for the single-stage cooling system are given below, respectively.

Evaporator Selection,

$$
\mathrm{Q}_{\mathrm{e}}=\dot{\mathrm{m}}_{717}\left(\mathrm{~h}_{4}-\mathrm{h}_{3}\right)
$$

Condenser Selection,

$$
\mathrm{Q}_{\mathrm{c}}=\dot{\mathrm{m}}_{717}\left(\mathrm{~h}_{1}-\mathrm{h}_{2}\right)
$$

Compressor Selection,

$$
\mathrm{Q}_{\text {comp }}=\dot{\mathrm{m}}_{717}\left(\mathrm{~h}_{1}-\mathrm{h}_{4}\right)
$$

The formulas used in the selection of system elements for the two-stage cooling system (Cascade) are listed below.

For the high temperature part (HT)

Evaporator Selection,

$$
\begin{array}{r}
\mathrm{Q}_{\mathrm{e}, \mathrm{HT}}=\dot{\mathrm{m}}_{717}\left(\mathrm{~h}_{7}-\mathrm{h}_{6}\right) \\
\text { Condenser Selection, } \\
\mathrm{Q}_{\mathrm{c}, \mathrm{HT}}=\dot{\mathrm{m}}_{717}\left(\mathrm{~h}_{3}-\mathrm{h}_{5}\right)
\end{array}
$$

Compressor Selection,

$$
\mathrm{Q}_{\text {comp }, \mathrm{HT}}=\dot{\mathrm{m}}_{717}\left(\mathrm{~h}_{2}-\mathrm{h}_{8}\right)
$$

For the low temperature part (HT)

Evaporator Selection,

$$
\mathrm{Q}_{\mathrm{e}, \mathrm{LT}}=\dot{\mathrm{m}}_{744}\left(\mathrm{~h}_{8}-\mathrm{h}_{6}\right)
$$

Condenser Selection,

$\mathrm{Q}_{\mathrm{C}, \mathrm{LT}}=\dot{\mathrm{m}}_{744}\left(\mathrm{~h}_{3}-\mathrm{h}_{5}\right)$

Compressor Selection,

$$
\mathrm{Q}_{\text {comp }, \mathrm{LT}}=\dot{\mathrm{m}}_{744}\left(\mathrm{~h}_{8}-\mathrm{h}_{2}\right)
$$

Moreover, the cooling performance of the system was calculated with equation 14 and the second law efficiency was calculated with equation 15.

Cooling performance of systems,

$$
\mathrm{COP}=\frac{\mathrm{Q}_{\mathrm{e}}}{\mathrm{W}_{\text {net }}}=\frac{\mathrm{Q}_{\mathrm{e}}}{\mathrm{W}_{\mathrm{HT}}+\mathrm{W}_{\mathrm{LT}}}
$$

Second law efficiency of systems,

$$
\eta_{\mathrm{II}}=\frac{\mathrm{COP}}{\mathrm{COP}_{\mathrm{tr}}}
$$

\section{FINDINGS AND DISCUSSION}

The findings obtained from the researches performed on the systems with the help of the equations given above are presented in Table 1 and 2 .

Table 1. Cooling load of system

\begin{tabular}{ll}
$\begin{array}{l}\text { The heat load from the cooling of the } \\
\text { ice cream (Eq.1) }\end{array}$ & $\begin{array}{l}\mathrm{Q}_{1 @ 200^{\circ} \mathrm{C}}=48.84 \mathrm{~kW} \\
\mathrm{Q}_{2 @ 4}{ }^{\circ} \mathrm{C}=26.30 \mathrm{~kW}\end{array}$ \\
\hline The heat from lighting fixtures (Eq.2) & $\mathrm{Q}_{\text {lighting }}=1.54 \mathrm{~kW}$ \\
\hline The heat from humans (Eq.2) & $\mathrm{Qhuman}=2.27 \mathrm{~kW}$ \\
\hline The heat from electric motors (Eq.3) & $\mathrm{Q}_{\text {fan motors }}=2.2 \mathrm{~kW}$ \\
\hline The heat from the rotary freezer (Eq.4) & $\mathrm{Q}_{\text {freezer }}=10.67 \mathrm{~kW}$ \\
\hline TOTAL & $\mathrm{Q}_{\text {total }}=91.82 \mathrm{~kW}$ \\
\hline
\end{tabular}

In the area where the ice cream machine is located, the total heat load was $91.82 \mathrm{~kW}$ and it was assumed that the total heat load was $101.3 \mathrm{~kW}$ with a $10 \%$ safety margin. In this case, the capacities of the selected system elements for both systems are presented in Table 2 .

The accuracy of the values obtained after the theoretical calculations were compared with the CoolPack cooling analysis program. The analyzes of the 
systems were given in Figure 5-6 and the found values in Table 3-6 respectively.

Table 2. Selection of system elements

\begin{tabular}{|c|c|}
\hline \multicolumn{2}{|c|}{ For the single-stage cooling system } \\
\hline \multicolumn{2}{|c|}{$\begin{array}{l}\mathrm{h}_{1}=1723.6 \mathrm{~kJ} / \mathrm{kg}=412.35 \mathrm{kcal} / \mathrm{kg} \\
\mathrm{h}_{2}=\mathrm{h}_{3}=291 \mathrm{~kJ} / \mathrm{kg}=69.62 \mathrm{kcal} / \mathrm{kg} \\
\mathrm{h}_{4}=1439.6 \mathrm{~kJ} / \mathrm{kg}=344.40 \mathrm{kcal} / \mathrm{kg} \\
\dot{\mathrm{m}}_{717}=0.08819 \mathrm{~kg} / \mathrm{s}\end{array}$} \\
\hline $\begin{array}{l}\text { Evaporator } \\
\text { Selection }\end{array}$ & $\begin{array}{l}\mathrm{Q}_{\mathrm{e}}=\mathrm{Q}_{\text {total }} \\
\mathrm{Q}_{\mathrm{e}}=\dot{\mathrm{m}} 717 \times(1439.6-291)=101.3 \mathrm{~kW}\end{array}$ \\
\hline $\begin{array}{l}\text { Condenser } \\
\text { Selection }\end{array}$ & $\mathrm{Q}_{c}=0.08819 \times(1723.6-291)=126.4 \mathrm{~kW}$ \\
\hline $\begin{array}{l}\text { Compressor } \\
\text { Selection }\end{array}$ & $Q_{\text {comp }}=0.08819 \times(1723.6-1439.6)=25.1 \mathrm{~kW}$ \\
\hline \multicolumn{2}{|c|}{ For the two-stage cooling system (Cascade) } \\
\hline \multicolumn{2}{|c|}{$\begin{array}{l}\text { High Temperature Part }(\mathrm{HT}) \\
\mathrm{h}_{5}=\mathrm{h}_{6}=291 \mathrm{~kJ} / \mathrm{kg}=69.62 \mathrm{kcal} / \mathrm{kg} \\
\mathrm{h}_{7}=1448.6 \mathrm{~kJ} / \mathrm{kg}=345.992 \mathrm{kcal} / \mathrm{kg} \\
\mathrm{h}_{8}=1451.2 \mathrm{~kJ} / \mathrm{kg}=346.613 \mathrm{kcal} / \mathrm{kg} \\
\dot{\mathrm{m}}_{717}=0.0875 \mathrm{~kg} / \mathrm{s}\end{array}$} \\
\hline $\begin{array}{l}\text { Evaporator } \\
\text { Selection }\end{array}$ & $\begin{array}{l}\mathrm{Q}_{\mathrm{e}}=\mathrm{Q}_{\text {total }}=101.3 \mathrm{~kW} \\
\mathrm{Q}_{\mathrm{e}}=\dot{\mathrm{m}}_{717}\left(\mathrm{~h}_{7}-\mathrm{h}_{6}\right) \\
\dot{\mathrm{m}}_{717}=0.0875 \mathrm{~kg} / \mathrm{s}\end{array}$ \\
\hline $\begin{array}{l}\text { Condenser } \\
\text { Selection }\end{array}$ & $Q_{c}=0.0875 \times(1682-291)=121.7 \mathrm{~kW}$ \\
\hline $\begin{array}{l}\text { Compressor } \\
\text { Selection }\end{array}$ & $Q_{\text {comp }}=0.0875 \times(1681.8-1451.2)=23.06 \mathrm{~kW}$ \\
\hline \multicolumn{2}{|c|}{ Low Temperature Part (LT) } \\
\hline $\begin{array}{l}\text { Evaporator } \\
\text { Selection }\end{array}$ & $\begin{array}{l}\mathrm{Q}_{\mathrm{e}}=\mathrm{Q}_{\mathrm{c}} \\
\dot{\mathrm{m}}_{744}=\dot{\mathrm{m}}_{717} \frac{\left(\mathrm{h}_{7}-\mathrm{h}_{6}\right)}{\left(\mathrm{h}_{3}-\mathrm{h}_{5}\right.} \\
\dot{\mathrm{m}}_{744}=0.36 \mathrm{~kg} / \mathrm{s} \\
\mathrm{Q}_{\mathrm{e}, \mathrm{LT}}=0.36 \times(-58.5-(-323.5))=95.4 \mathrm{~kW}\end{array}$ \\
\hline $\begin{array}{l}\text { Condenser } \\
\text { Selection }\end{array}$ & $\mathrm{Q}_{\mathrm{c}}=101.3 \mathrm{~kW}$ \\
\hline $\begin{array}{l}\text { Compressor } \\
\text { Selection }\end{array}$ & $Q_{\text {comp }}=0.36 \times(42.4-(-58.5))=16.1 \mathrm{~kW}$ \\
\hline
\end{tabular}

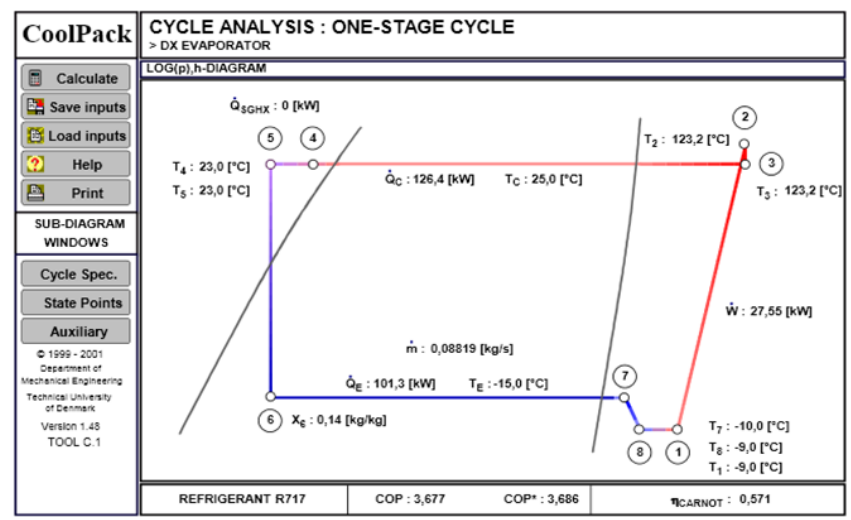

Figure 5. Input values of the single-stage cycle examined in the CoolPack

Furthermore, it has been seen that the COP value of the single stage refrigeration cycle was 3.67 , the pressure ratio $\left(\mathrm{P}_{2} / \mathrm{P}_{1}\right)$ was 4.418 , the $\mathrm{T}_{2.1 \text { s value was }} 98^{\circ} \mathrm{C}$ and the $\mathrm{T}_{2, \mathrm{w}}$ value was $135^{\circ} \mathrm{C}$. In this expression, $\mathrm{T}_{2.1 \mathrm{~s}}$ value is the temperature of the discharge gas assuming eversible and adiabatic compression. In the same way, $\mathrm{T}_{2,}$ w value is the temperature of the discharge gas assuming real and adiabatic compression.

If Figure 4-6 and Table 3-6 are examined, lower and upper stage evaporation and condensation temperatures of each cycle, heating and cooling capacities, compressor powers, heat loss rates of compressors, overcooling, overheating, unuseful superheating temperature differences and pressure losses can be seen.

Table 3. Values at each point of the single-stage cycle

\begin{tabular}{ccccc}
\hline $\begin{array}{c}\text { State } \\
\text { Point }\end{array}$ & $\begin{array}{c}\text { Temperature } \\
\left({ }^{\circ} \mathrm{C}\right)\end{array}$ & $\begin{array}{c}\text { Pressure } \\
(\mathrm{kPa})\end{array}$ & $\begin{array}{c}\text { Enthalpy } \\
(\mathrm{kJ} / \mathrm{kg})\end{array}$ & $\begin{array}{c}\text { Density } \\
\left(\mathrm{kg} / \mathrm{m}^{3}\right)\end{array}$ \\
\hline 1 & -9.0 & 231.2 & 1442.4 & 1.9 \\
2 & 123.2 & 1021.6 & 1723.6 & 5.5 \\
3 & 123.2 & 1006.0 & 1724.0 & 5.4 \\
4 & 23.0 & 1006.0 & 291.0 & 605.8 \\
5 & 23.0 & 1006 & 291.0 & 605.8 \\
6 & -15.0 & 236.2 & 291 & - \\
7 & -10.0 & 236.2 & 1439.6 & 1.9 \\
8 & -9.0 & 231.2 & 1442.4 & 1.9 \\
\hline
\end{tabular}

Table 4. Supporting information on the single-stage cycle

\begin{tabular}{ccc}
\hline \multicolumn{3}{c}{ Cooling Capacity } \\
\hline $\mathrm{Q}_{\mathrm{e}}=101.3 \mathrm{~kW}$ & $\mathrm{Q}_{\mathrm{c}}=126.4 \mathrm{~kW}$ & $\dot{\mathrm{m}}=0.08819 \mathrm{~kg} / \mathrm{s}$ \\
\hline \multicolumn{3}{c}{ Compressor Performance } \\
\hline \multicolumn{3}{c}{ Compressor Heat Loss } \\
\hline $\begin{array}{c}\text { Heatloss factor } \\
\mathrm{f}_{\mathrm{Q}}=10 \%\end{array}$ & $\mathrm{~T}_{2}=123.2{ }^{\circ} \mathrm{C}$ & $\mathrm{Q}_{\text {loss }}=2.755 \mathrm{~kW}$ \\
\hline $\begin{array}{c}\text { Unuseful } \\
\text { superheat }\end{array}$ & $\mathrm{Q}_{\mathrm{sL}}=0.249 \mathrm{~kW}$ & $\mathrm{~T}_{\mathrm{s}}=-9{ }^{\circ} \mathrm{C}$ \\
\hline
\end{tabular}

For the two-stage cascade cooling system

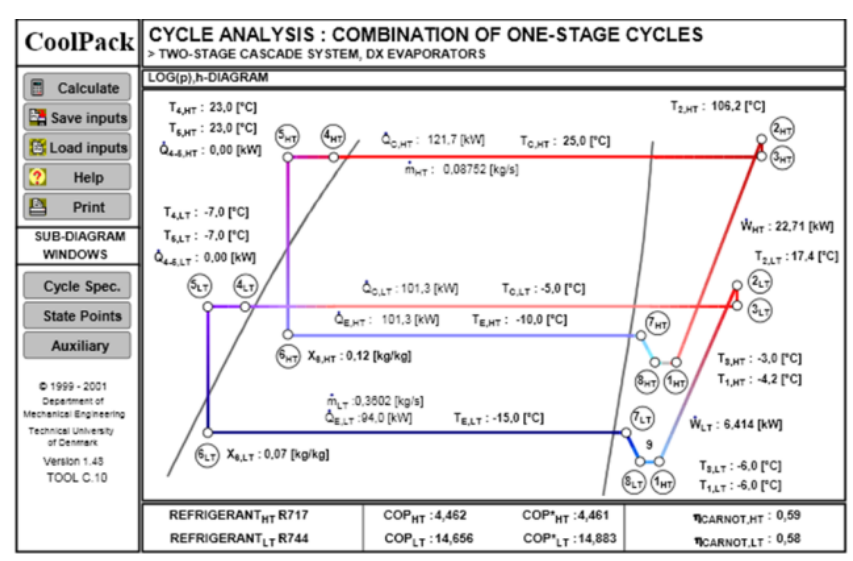

Figure 6. Input values of the cascade cycle examined in CoolPack

\section{CONCLUSIONS}

In this study, a single-stage cooling system with R717 refrigerant and a cascade cooling system with R717/R744 system were compared with each other. As a result of the calculations, an evaporator load of $101.3 \mathrm{~kW}$ was found and a comparison was made for a system operating in the temperature range $\left(25^{\circ} \mathrm{C},-15^{\circ} \mathrm{C}\right)$ following the freezing production steps.

The calculations were made both manually and with the Coolpack program and the results were confirmed. As a result of the calculations, the COP value of the singlestage system was calculated as 3.67 , the Carnot efficiency 0.57, the second law efficiency 0.19 and the power required to operate the compressor was $27.55 \mathrm{~kW}$. In the cascade cooling system, the COP value was 4.46 , the Carnot efficiency 0.59 and the compressor power 22.7 
$\mathrm{kW}$ at the high-temperature part, the COP value was 14.656, the Carnot efficiency 0.58 and the compressor power $6.4 \mathrm{~kW}$ at the low-temperature part. For the whole cascade system, the COP 3.24 and the second law efficiency were found to be 0.43 . When the results compared, it was seen that the COP values of the high and low-temperature parts of the cascade system were higher than the single-stage ammonia system, but when evaluated for the whole system, the COP value was less than 0.43 points. However, the usage of the cascade system is important when considering the fact that the cooling system will be used in the food sector and reducing environmental damage, as well as reducing the heat and losses emitted by decreasing compressor pressure rates.

Besides, considering both the climatic conditions of our country and the thermo physical properties of carbon dioxide gas, it was seen that the most suitable design that can use carbon dioxide gas is the cascade cooling system. Usage of the carbon dioxide in the lowtemperature cycle of the cascade system eliminates the disadvantage of high pressure caused by the low triple point $\left(31^{\circ} \mathrm{C}\right)$ and increases its usability in this system since carbon dioxide has a positive effective pressure even at temperatures as low as $-55^{\circ} \mathrm{C}$. The minimum temperature that can be achieved when ammonia used in a low-temperature cycle is $-35^{\circ} \mathrm{C}$. The pressure of ammonia gas below this temperature falls below the atmospheric pressure and it circulates with the air-fluid, causes damage to the equipment due to moisture in it, leads leakage, and poisoning. However, carbon dioxide does not have such disadvantages and provides optimum operation at $-10^{\circ} \mathrm{C}$. In conclusion, the overall superiorities of carbon dioxide make it a highly suitable secondary refrigerant for the cascade system.

Table 5. Values at each point of the cascade cycle

\begin{tabular}{ccccc}
\hline \multicolumn{5}{c}{ High Temperature (HT) } \\
$\begin{array}{ccccc}\text { State } \\
\text { Point }\end{array}$ & $\begin{array}{c}\text { Temperature } \\
\left({ }^{\circ} \mathrm{C}\right)\end{array}$ & $\begin{array}{c}\text { Pressure } \\
(\mathrm{kPa})\end{array}$ & $\begin{array}{c}\text { Enthalpy } \\
(\mathrm{kJ} / \mathrm{kg})\end{array}$ & $\begin{array}{c}\text { Density } \\
\left(\mathrm{kg} / \mathrm{m}^{3}\right)\end{array}$ \\
\hline 1 & -4.2 & 288.6 & -4.2 & 2.3 \\
2 & 106.2 & 1012.2 & 1681.8 & 5.7 \\
3 & 106.2 & 1006.0 & 1682.0 & 5.7 \\
4 & 23.0 & 1006.0 & 291.0 & 605.8 \\
5 & 23.0 & 1006.0 & 291.0 & 605.8 \\
6 & -10.0 & 290.9 & 291.0 & - \\
7 & -4.0 & 290.9 & 1448.6 & 2.3 \\
8 & -3.0 & 288.6 & 1451.2 & 2.3 \\
9 & -4.2 & 288.6 & 1448.3 & 2.3 \\
\hline \multicolumn{5}{c}{ LowTemperature $(\mathrm{LT})$} \\
\hline State & Temperature & Pressure & Enthalpy & Density \\
Point & $\left({ }^{\circ} \mathrm{C}\right)$ & $(\mathrm{kPa})$ & $(\mathrm{kJ} / \mathrm{kg})$ & $\left(\mathrm{kg} / \mathrm{m}^{3}\right)$ \\
\hline 1 & -6.0 & 2277.2 & -58.5 & 55.9 \\
2 & 17.4 & 3062.5 & -42.4 & 69.1 \\
3 & 17.4 & 3045.8 & -42.2 & 68.7 \\
4 & -7.0 & 3045.8 & -323.5 & 968.3 \\
5 & -7.0 & 3045.8 & -323.5 & 968.3 \\
6 & -15.0 & 2290.7 & -323.5 & - \\
7 & -9.0 & 2290.7 & -62.5 & 57.7 \\
8 & -6.0 & 2277.2 & -58.5 & 55.9 \\
9 & - & - & - & - \\
\hline
\end{tabular}

Table 6. Supporting information on the cascade cycle

\begin{tabular}{|c|c|c|}
\hline \multicolumn{3}{|c|}{ Cycle Capacity } \\
\hline \multicolumn{3}{|c|}{ High Temperature (HT) } \\
\hline $\mathrm{Q}_{\mathrm{e}, \mathrm{HT}}=101.3 \mathrm{~kW}$ & & $\dot{\mathrm{n}}=0.08752 \mathrm{~kg} / \mathrm{s}$ \\
\hline \multicolumn{3}{|c|}{ Compressor Performance } \\
\hline Isantropic efficiecy, $\eta$ & $=0.7 \quad \mathrm{~V}$ & $\mathrm{~W}_{\mathrm{HT}}=22.71 \mathrm{~kW}$ \\
\hline \multicolumn{3}{|c|}{ Compressor Heat Loss } \\
\hline Heat loss factor $\mathrm{f}_{Q}=10 \%$ & $\mathrm{~T}_{2}=106.2^{\circ} \mathrm{C}$ & $Q_{\text {loss }}=2.3 \mathrm{~kW}$ \\
\hline \multicolumn{3}{|c|}{ Suction Line } \\
\hline Unuseful superheat & $\mathrm{Q}_{\mathrm{sL}}=0.228 \mathrm{~kW}$ & $\mathrm{~T}_{\mathrm{s}}=-3^{\circ} \mathrm{C}$ \\
\hline \multicolumn{3}{|c|}{ Low Temperature (LT) } \\
\hline $\mathrm{Q}_{\mathrm{e}, \mathrm{LT}}=94 \mathrm{~kW}$ & $\dot{\mathrm{m}}=0$ & $0.3602 \mathrm{~kg} / \mathrm{s}$ \\
\hline \multicolumn{3}{|c|}{ Compressor Performance } \\
\hline Isantropic efficiecy, $\eta$ & $=0.7 \quad \mathrm{~V}$ & $\mathrm{~W}_{\mathrm{LT}}=6.414 \mathrm{~kW}$ \\
\hline \multicolumn{3}{|c|}{ Compressor Heat Loss } \\
\hline Heat loss factor $\mathrm{f}_{\mathrm{Q}}=10 \%$ & $\mathrm{~T}_{2}=17.4^{\circ} \mathrm{C}$ & $Q_{\text {loss }}=0.6 \mathrm{~kW}$ \\
\hline \multicolumn{3}{|c|}{ Suction Line } \\
\hline Unuseful superheat & $\mathrm{Q}_{\mathrm{sL}}=1.456 \mathrm{~kW}$ & $\mathrm{~T}_{\mathrm{s}}=-6^{\circ} \mathrm{C}$ \\
\hline $\begin{array}{l}\text { For the whole system; } \\
\text { Total compressor powe }\end{array}$ & \multicolumn{2}{|c|}{$\mathrm{W}_{\text {tot }}=29.12 \mathrm{~kW}$} \\
\hline
\end{tabular}

\section{REFERENCES}

Alan A (2011). Effect of usage of expander to energy potential at two stages $\mathrm{CO}_{2}$ refrigeration systems, MSc Thesis, University of Süleyman Demirel, Isparta, Turkey.

Bingming W, Huagen W, Jianfeng L \& Ziwen X (2009). Experimental investigation on the performance of $\mathrm{NH}_{3} / \mathrm{CO}_{2}$ cascade refrigeration system with twinscrew compressor. International Journal of Refrigeration, 32(6), 1358-1365. DOI: 10.1016/j.ijrefrig.2009.03.008

Çerkezoğlu B (2010). Analysis of a cascade refrigeration system using $\mathrm{CO}_{2}$ as a refrigerant. MSc Thesis, Istanbul Technical University, Istanbul, Turkey (in Turkish).

Dopazo J A \& Fernández-Seara J (2011). Experimental evaluation of a cascade refrigeration system prototype with $\mathrm{CO} 2$ and NH3 for freezing process applications. International Journal of Refrigeration, 34(1), 257-267. DOI: 10.1016/j.ijrefrig.2010.07.010

Dopazo J A, Fernández-Seara J, Sieres J \& Uhía F J (2009). Theoretical analysis of a $\mathrm{CO}-\mathrm{NH}$ cascade refrigeration system for cooling applications at low temperatures. Applied Thermal Engineering, 29(89), 1577-1583. DOI: 10.1016/j.applthermaleng.2008.07.006

Getu H M \& Bansal P K (2007). Modeling and performance analysis of evaporators in frozen food supermarket display cabinets at low temperatures. International Journal of Refrigeration, 30(7), 12271243. DOI: $10.1016 /$ j.ijrefrig.2007.02.003

Kasap F, Acül H, Canbaz H \& Erbil S (2011). R744 $\left(\mathrm{CO}_{2}\right)$ Refrigerant cooling systems, finned tube R744 $\left(\mathrm{CO}_{2}\right)$ evaporator and gas cooler design principles. X. National Installation Engineering Congress, İzmir, Turkey, 391-410.

Onbaşığlu H (2010). An overview of vapour compression system using natural refrigerant $\mathrm{CO}_{2}$. İSKID ACV\&R Journal of Turkey, 2, 48-64.

Özyurt A, Erdönmez N, Yilmaz B, Yilmaz D, Sevindir M K \& Mançuhan E (2016). Thermodynamic analysis and performance evaluation of $\mathrm{CO}_{2} / \mathrm{NH}_{3}$ Cascade 
Cooling System. Tesisat Mühendisliği, 155, 10991110.

Rezayan 0 \& Behbahaninia A (2011). Thermoeconomic optimization and exergy analysis of $\mathrm{CO}_{2} / \mathrm{NH}_{3}$ cascade refrigeration systems. Energy, 36(2), 888895. DOI: 10.1016/j.energy.2010.12.022

Vestergaard N P (2007). $\mathrm{CO}_{2}$ refrigerant for industrial refrigeration. Danfoss A/S (RA Marketing/MWA), DKRCI.PZ.000.C1.02 / 520H2242.
(ㄷ) (1)

(C) Author(s) 2021.

This work is distributed under https://creativecommons.org/licenses/by-sa/4.0/ 